Article

\title{
Entrepreneurial motivational factors and operational performance of small-scale industries in Yanya
}

\author{
Mohammed Abubakar Mawoli ${ }^{1}$ and Ugbedeojo Nelson Peter ${ }^{2}$ \\ 1 Department of Business Administration, Ibrahim Badamasi Babangida University, Lapai; \\ iammawoli@gmail.com \\ 2 Department of Business Administration, Kogi State University, Anyigba; ugbedeojonelsonpeter@gmail.com. \\ Correspondence: Dr Mohammed Abubakar Mawoli; iammawoli@gmail.com; +23480 36114904; Department \\ of Business Administration, Ibrahim Badamasi Babangida University, Lapai, Niger State, Nigeria
}

Received: 9 February 2021; Accepted: 17 May 2021; Published: 26 May 2021

\begin{abstract}
To address the growing labour unemployment rate in Nigeria, several hard and soft intervention policies have been put in place by the Nigerian government and supporting partners. Based on the assumption that unemployment, government interventions, and personal ambition can motivate individuals into entrepreneurship, this study examined the effect of entrepreneurial motivational factors on the operational performance of Small Scale Industries (SSIs) located in Yanya, Abuja. Relying on a cross-sectional survey research design, 337 practicing entrepreneurs, random sampling technique and multiple regression analysis, the study found that facilitating and compelling motivational factors are the significant predictors of SSIs' performance, while ambitious motivational factor is negatively but significantly impactful on SSIs' performance. It, therefore, suffices to recommend that the Nigerian government and organized private sector should collaborate to increase the stock of hard and soft infrastructure, especially in the industrial estates and business clusters, to enhance entrepreneurship participation and inclusiveness
\end{abstract}

Keywords: Motivation, Entrepreneurship, Industry , Performance, Nigeria

JEL codes: M50

\section{Introduction}

Entrepreneurship is a key determinant of current and future incomes and jobs in all economies (GEM, 2019). Entrepreneurship and/or private enterprises provide self-employment, family employment, and third-party/public employment to the Nigerian labour force put at 52.5 percent of the country's over 200 million population (NBS, 2020:46). The private sector, driven by business persons and entrepreneurs, employs over 65 and 58 percent of the male and female workforce respectively (NBS, 2020:57); majority of the enterprises are located in urban areas like Abuja and its suburbs that extends to neighboring states such as Yanya in Nasarawa State (NBS, 2020).

The private sector has greater potentials to create new jobs, absorb unemployed youths into pay jobs and ameliorate the poverty rate if the existing and prospective entrepreneurs are motivated to among others, expand existing entrepreneurial establishments, sets-up new firms, innovate disruptive products, and produce future entrepreneurs. Frese and Gielnik (2014) affirm that entrepreneurial motivation involves an entrepreneur's desire to engage in self start-ups and/or create something new based on internal impetus. Entrepreneurs can be motivated by several factors: psychological and nonpsychological motivation (Ullah, Farooq, and Ahmad, 2012), economic and non-economic motivation (Boada-Grau, Sachez-Gercia, Viardot, E. Boada-Cuerva and Vigil-Colet, 2016), intrinsic and extrinsic motivation (Anton van de Rijdt, 2014), personal, cognitive and affective motivation (Yitshaki and 
Kropp, 2018), internal and external motivation (Vijaya and Kamalanabhan, 1998), individual and contextual motivation (Hossain, Al Asheq and Arifuzzaman, 2019), push and pull motivation (Robichaud, Cachon and Haq, 2010), and opportunity and necessity motivation (Reynolds, Camp, Bygrave, Autio and Hay, 2001), which can be subsumed into ambitious, compelling and facilitating factors of motivation if re-jigged (Murthy, Chandrashekhar, and Rao, 1986; Gangadhara-Rao, 1986; Kishore, Raju and Dasaraju, 2012; Lalhunthara, 2012). Ambitious motivation relates to the entrepreneurs' desire to be independent, to perform, earn income, and contribute to the society and local environment, which energize entrepreneurs to set up enterprises and work hard to ensure their success (Stam, Bosma, Witteloostuijn, Jong, Bogaert, Edwards, and Jasper, 2012). Compelling motivation relates to entrepreneurs' desire to escape from unemployment, poverty, lack of alternative career opportunities, job dissatisfaction, and job insecurity, which further pushes them to establish startups and work hard to ensure their survival and progress (Lalhunthara, 2012). Facilitating motivation are concerned with enabling environment (basic infrastructure, access to funds, security), business opportunities, family support, and government incentives (Lalhunthara, 2012; GangdharaRao, 1986).

Just as motivation is associated with workers' productivity and organizational performance (Kuranchie-Mensah andAmponsah-Tawiah, 2016; Dobre, 3013; Mawoli and Babandako, 2011; Abdusalam and Mawoli, 2012), entrepreneurial motivation is equally a determinant of entrepreneurial firm performance in countries such as France (Gundolf, Gast and Geraudel, 2017), Malysia (Nasib, Sulong and Amirul, 2019) and Pakistan (Tanveer, Zafar,, Shafique and Jhangir, 2013). However, entrepreneurship researchers in Nigeria are yet to sufficiently ratify this claim which provokes this inquiry on the effect of entrepreneurial motivation factors (e.g. ambitious, compelling, and facilitating entrepreneurial motivation) on the operational performance of SMES in Yanya, Abuja suburb. Consequently, the following hypotheses are postulated for testing:

$\mathrm{H}_{\text {o1: }}$ Ambitious entrepreneurial motivation is not a significant predictor of SSI operational performance.

$\mathbf{H}_{\text {o2: }}$ Compelling entrepreneurial motivation does not significantly predict SSI operational performance.

$\mathbf{H}_{\mathbf{0}}$ : Facilitating entrepreneurial motivation is not a significant predictor of SSI operational performance.

This study can guide policy makers at national and sub-national levels as regards the motivational factors that are most potent in boosting SMEs' operational performance, most especially in Yanya and other urban areas in Nigeria. Currently, entrepreneurial finances through government banks such as Anchor Borrowers Funds (ABF) and Agricultural Small and Medium Enterprises Equity Investment Scheme (AGSMEIS) of Central Bank of Nigeria, and Nigeria Youth Investment Funds (N-YIF) of NIRSAL Microfinance Bank is in the front burner, followed by business support infrastructure in few business clusters across the country, and the declaration by the Federal Government of Nigeria to lift a hundred million Nigerians out of poverty from years 2020 to 2030.

The literature scope of the study revolves around entrepreneurial motivation and enterprise performance. The operational scope of the study is limited to small scale industries operating in Yanya as of year 2020 .

The rest of the paper is structured as follows: the 'literature review' where conceptual issues were addressed and findings of relevant earlier studies were reported; the 'methodology' where the research design, data collection and analysis techniques were explained; the 'results and findings' where outcomes of hypotheses testing were presented and discussed; and the 'conclusions and recommendations where the research findings were summarized and as well generalized for the entire population, and the ways forward suggested. 


\section{Literature Review}

\subsection{Conceptual review}

Concepts that are translated to research variables at the methodological stage and beyond (e.g. entrepreneurial motivation; ambitious, compelling and facilitating motivation; and performance) are reviewed under.

\subsubsection{Entrepreneurial motivation}

Generally, motivation is an inner drive and external inducement that propel individuals into action or behavior that is purposeful, goal-oriented and rewarding (Dess and Robinson, 1984; Kreitner, 1989). Specifically, entrepreneurial motivation is a combination of psychological attribute of individual entrepreneurs and external or environmental factors that stimulate entrepreneurial actions in the forms of market opportunity exploration, product/innovation development, venture establishment, business management, business expansion and diversification, and business performance (Shane, 2003; Kirkwood, 2009). Clarifying further, Naffzinger, Hornsby and Kuratko (1994) stress that entrepreneurial motivation is about decision to either engage in entrepreneurial behavior or not. Entrepreneurial motivation can be categorized into ambitious, compelling and facilitating motivation (Gangadhara-Rao, 1986; Kishore, Raju and Dasaraju, 2012).

\subsubsection{Ambitious motivation}

Ambitious motivation, in the entrepreneurship context, is associated with entrepreneur's aspirations and determination to achieve business related goals (Das, 2016), notably owning a business enterprise, developing innovative products, realizing profit and attaining prestigious position in the society. According to Stam, et'al. (2012), an ambitious entrepreneur identifies and exploits opportunities to create new products, services, processes and organizations with high aspiration to achieve entrepreneurial success - maximizing value creation beyond self sufficiency.

Beyond individual level, a group, family, organization and nation can be motivated by the ambition to achieve certain entrepreneurial goals, which explains why some human groupings are more innovative and prosperous than others (Lalhunthara, 2013). Importantly, personal ambition can be instilled and gingered by one's family, organization and nation's aspiration, and vice-versa. Entrepreneur's ambitions provide the basis for the McClelland's "need-for-achievement" factor.

\subsubsection{Compelling motivation}

Compelling motivation is a situation whereby an individual is pushed by unemployment, poverty and job dissatisfaction to choose entrepreneurship as an occupation (Rao, Venkatachalm and Joshi, 2013). That is, the Maslow's physiological factors such as lack of food, clothing and shelter (including inability to afford basic healthcare and education) are the key drivers and motivators of the compelling entrepreneurship. Here, basic human needs, necessities of life, and compulsion (family/dependent's pressure) rather than personal ambition lead people to try entrepreneurship as a self-sustenance career path (Lalhunthara, 2013), and in the process discover compatibility of their personality traits with entrepreneurship traits, then later acquire and perfect new entrepreneurial skills, and finally stick to entrepreneurship as occupation.

\subsubsection{Facilitating motivation}

This is concerned with family encouragement (moral, financial and material support) (Lalhunthara, 2013; Narasimha-Murthy, 1989; Kishore, et'al., 2012) and government incentives (Kishore, et'al., 2012) that drives individual to participate in entrepreneurship and energizes them to work hard to succeed. Sayyar, Latifi, Sarempoor and Pirmoradi (2012) classified entrepreneurial facilitating factors as educational factor (existence of entrepreneurship schools/curriculum, practical 
courses, practical skills), financial and legal factors (access to finance and tax legislation/relief), infrastructural factor, and cultural factor.

\subsubsection{Operational Performance}

Heizer (2008) sees operational performance as the ability of a company to reduce management costs, order-time, lead-time, and improve the effectiveness of using raw material and distribution capacity. Venkataraman (1997) defines operational performance as consisting of key parameters which may lead to an improvement in financial performance, namely market share, new product introduction, product quality, marketing effectiveness, manufacturing or value-addition, and innovation within the domain of business performance. The operational performance objectives can be summarized as quality, cost, speed, dependability and flexibility (Slack, 2004; Hill, 2000). Lin (2007) proposed that subjective performance and non-financial measures (e.g. operational performance) be applied in evaluating performance of SMEs.

\subsection{Empirical review}

Nisula, Olander and Henttonen (2017) reported from their study that entrepreneur-expert creativity (creative performance) is driven by materialism, achievement and power motivation. Baraba-Sanchez and Atienza-Sahuquillo (2012) found that certain ambitious factors (need for achievement, self-realization, independence, affiliation, competence and power) have more influence on entrepreneurial behavior than wealth or money-making ambition. Similarly, Tanveer et'al. (2013) ratified that students' entrepreneurial intention is significantly influenced by motivational factors such as desire for independence, job security, income, challenging career, role model (the ambitious factors); market opportunity and investment capital (the facilitating factors) in Pakistan. Rao, et'al. (2013) empirically attest that women entrepreneurs are motivated to start a new business by their ambition. Gundolf et'al. (2017) confirmed through their research that independence, income and role-model (the ambitious factors) exerted significant effect on startups' diversified innovation behavior in France; also, unemployment (the compelling factor) and market-driving (the facilitating) factor significantly motivated startups' diversified innovative behavior in France.

Furthermore, Farzana's (2018) study showcased that 'need-for-achievement' significantly affected entrepreneurial intention, while variables such as financial, self-efficacy and independence motivation did not influence entrepreneurial intention. A study by Nasib et'al. (2019) established that entrepreneurs in Sabah are motivated by the available entrepreneurial opportunities (facilitating factors) rather than entrepreneurial necessities (compelling factors). Ogonaike, Aribisala, Ayeni and Osoko's (2019) study manifest that 'need for love and belonging' (affection motivation) is the strongest predictor of entrepreneurial performance in Nigeria; followed by 'physiological needs' (necessity/compelling motivation). Kishore et'al. (2012) found that "to earn money" and "to fulfill the ambition of self/parents/spouse" take lead with $64 \%$ and $53.3 \%$ respectively in a 6-item scale of ambitious entrepreneurial motivation; "dissatisfaction with the previous job/occupation" and "unemployment" take lead with $74.7 \%$ and $53.3 \%$ respectively in a 6-item scale of compelling entrepreneurial motivation; and "previous employment experience in the same line or related industry", "sufficient money and property in hand", and encouragement of relations/friends/spouse" take lead with $73.3 \%, 53.3 \%$ and $50,7 \%$ in a 7 -item scale that measured facilitating entrepreneurial motivation.

In contrast, the finding of Tettey (2014) is that motivation factors (resource availability, entrepreneurial traits, push factor, and pull factor) have no significant impact on firm performance. Bourles and Cozarenco (2018) revealed that necessity entrepreneurs are significantly more likely to record poor business performance in France; that is, necessity motivation has no significant effect on business survival. 


\subsection{Theoretical framework}

Both ambitious and compelling entrepreneurial motivations are casted on the content theory of motivation. The content theory of motivation focuses on 'what' motivates individuals to partake in entrepreneurship (venture creation, product innovation, etc.) (Black, Bright, Gardner and Hartmann, 2019); the need theories of motivation fall within this category. Specifically, the link between ambitious entrepreneurial motivation and enterprise performance is premised on 'achievement motivation theory' of McLelland (1961). McLelland (1961) theorized that entrepreneurs have high need-forachievement (n-Ach) as they are more likely to engage in task-oriented, skill-dependent, goal-focused, and moderately risky activities whose outcome or performance is put under their responsibility. Langton, Robbins and Judge (2016:132) define need-for-achievement motivation as "the drive to excel, to achieve in relation to a set of standards, and to strive to succeed", while Brody and Ehrlichman (1998:191) describe need-for-achievement motivation as "the drive to do something better"; meaning, the drive to add value, to bring about change, and to be rewarded with income (salary) and profits, which are the hallmarks of entrepreneurship. Studies by Johnson (1990), Collins, Locke and Hanges (2000) and Charles and Gherman (2013) proved that successful entrepreneurs have high need-forachievements. The relevance of this theory to the current study hinges on the fact that, firms are preplanned entities which require effective management and growth after their establishment for sustenance; thus, only the caliber of individuals that have passion for setting difficult but achievable goals, harnessing the resources, skill and talents to pursue the pre-determined goals to logical conclusions despite underlying risks can conceive, establish, manage and expand entrepreneurial firms. In addition, the relationship between compelling entrepreneurial motivation and enterprise performance is anchored on the 'existence need motivation' theory of Alderfer (1972) - aggregation of physiological and safety needs of Maslow's theory of motivation. The theory postulates that both unsatisfied physiological and job-security needs drive people to engage in entrepreneurial activities for financial rewards (salary and profit), which are used to acquire basic goods in order to satisfy the physiological needs. However, sustainability of the individual's satisfaction state in the long-run depends largely on the performance of the business enterprise which s/he has established.

On the other hand, the facilitating entrepreneurial motivation is casted on the 'process theory of motivation' which concentrates on and explains 'how' individuals are motivated to engage and prosper in entrepreneurial ventures (Black, et. al. 2019). Precisely, the nexus between facilitating entrepreneurial motivation and enterprise performance is rooted in contextual/situational/external motivational theories. According to Black et'al. (2019), motivation may be a force outside the body such as incentives (training schemes, free/subsidized business registration, tax relief, access to finance, financial loans, business infrastructure, etc.) that stimulates, energizes, direct and sustain an entrepreneur's behavior

\section{Methodology}

\subsection{Research design}

The stated research objectives dictate that the quantitative survey research design be used. Additionally, explanatory research design was employed to determine the extent to which changes in the performance of small scale industries in explained by the ambitions, compelling and facilitating motivations.

\subsection{Population and sample}

The units of analysis are start-up entrepreneurs Precisely, 337 small-scale industry (SSIs) entrepreneurs out of a total population of 2,122 SSIs in New-Yanyan (Social Welfare Office, 2020) were randomly sampled as dictated by the sample size estimation formula of Guilford and Fruchter (1973). 


\subsection{Data collection instrument and measurement of variables}

A structured questionnaire was used to gather primary data. The questionnaire is divided into three sections: bio-data of respondents occupies section one; motivational factors (ambitious, compelling and facilitating motivation) is situated in section two; and operational performance is placed in section three. Apart from section one that contains dichotomous and multiple-choice questions, the remaining sections contain 5-point Likert's scale statements.

The research variables (entrepreneurial motivation and performance) were measured using multi-item 5-points summated Likert's scale. Precisely, the independent variable (entrepreneurial motivation) is measured using three determinants: ambitious, compelling and facilitating motivational factors. The ambitious motivation scale adapted from the works of Lalhunthara (2012) and Kishore et'al. (2012) is made up of five items, namely: I set up and manage a small-scale industry because of my desire to make a profit (profit motive), I set up and manage a small-scale industry because of my desire to compete for customers, suppliers and sales win (competitive motive), I set-up and manage a small-scale industry because of my desire to lead employees towards achieving common goals (leadership motive), I set-up and manage a small-scale industry because of my desire to manage scarce resources (management motive), and I set-up and manage a small-scale industry because of my desire to own a business organization (business-ownership motive).

The compelling motivation scale adapted from the works of Kishore et'al. (2012) and Lalhunthara (2012) consists of six items: unemployment made me work hard to establish a small-scale industry (unemployment motive), dissatisfaction with the job made me to establish a small-scale industry (job dissatisfaction motive), family pressure and responsibilities made me work hard to set-up a small scale industry (family motives), the need to make use of my technical and professional skills (skills motive), lack of alternative career opportunities made me to set-up a small-scale industry (career nonavailability motive), and Lack of basic needs of life made me to establish a small-scale industry (poverty motive).

However, the scale for facilitating motivation was adapted from Fereidouni, Masron, Nikbin and Amiri (2010), Kishore et'al. (2012) and Lalhunthara (2012) and contains seven items: I was motivated to set-up a small-scale industry because of adequate electricity supply, I was motivated to set-up a small-scale industry because of availability of good roads, I was motivated to set-up a small-scale industry because of adequate water supply, I was motivated to set-up a small-scale industry because of access to loan facilities, I was motivated to set-up a small-scale industry because of access to telecommunication facilities, I was motivated to set-up a small-scale industry because of access to educational and training facilities, and I was motivated to set-up a small-scale industry because of tax holiday/waiver incentives.

Furthermore, the dependent variable (operational performance) is made up of 18-item scale, namely: number of bad products returned by the customer has reduced; quantity of waste, discards and reworks has reduced; numbers of defective finished or intermediate products have reduced; our product and service quality has increased in the eyes of the customers; total cost in the production process has reduced; total cost in the internal and external logistic processes have reduced; processing costs have reduced; personnel efficiency has increased; replacement rate of the equipment assigned to each worker has reduced depending on the changing work priorities; ability of the manufacturing personnel to work at various and different functions has improved; flexibility to change the work priorities depending on the orders has improved; ability to use the existing equipment and personnel flexibility for production of the non-standard products has improved; ability to produce nonstandard products according to different customer order has improved; time between receipt of purchase order and delivery has decreased; delivery speed of the finished products has increased; time between start of the product process and delivery has decreased; ability to keep the promises given previously for delivery has improved; and ability to deliver on just-in-time has improved (adapted from Basheikh and Abdel-Maksoud, 2008; and Hadli, nd.). 


\subsection{Reliability test}

Table 1 shows the results of Cronbach alpha reliability test: ' ambitious scale' is reliable by $69.9 \%$, 'compelling scale' is reliably by $76.6 \%$, 'facilitating scale' is reliable by $64.4 \%$, and 'performance scale' is reliable by $80.7 \%$.

Table 1. Reliability Test

\begin{tabular}{cccc}
\hline Variables & $\begin{array}{c}\text { No of } \\
\text { items }\end{array}$ & $\begin{array}{c}\text { Average interim } \\
\text { covariance }\end{array}$ & $\begin{array}{c}\text { Scale reliability } \\
\text { coefficient }\end{array}$ \\
\hline Ambitious mot. & 5 & 0.077887 & 0.6994 \\
\hline Compelling mot. & 6 & 0.4164812 & 0.7662 \\
\hline Facilitating mot. & 7 & 0.2028604 & 0.6449 \\
\hline Performance & 18 & 0.3109281 & 0.8076 \\
\hline
\end{tabular}

Source: Field survey, 2020

\subsection{Method of data analysis}

Mean, standard deviation (sd), variance, skewness, kurtosis, and correlation statistics were processed to ascertain the suitability of the research data for regression test. The research hypotheses were tested using multiple linear regression at $5 \%$ level of significance. The regression model is given below:

$$
\mathrm{OP}=\beta 0+\beta 1 \mathrm{AM}+\beta 1 \mathrm{CM}+\beta 1 \mathrm{FM}+\mathrm{e}
$$

Where: OP - operational performance; $\beta_{0}$ - constant; $\beta_{1}-\beta_{3}$ - coefficients; $\mathrm{AM}$ - Ambitions Motivation; CM - Compelling Motivation; FM - Facilitating motivation; e - error term.

\section{Results}

\subsection{Response and SSI background information}

In this section, the outputs of data analyses are presented in tables and interpreted accordingly. To start with, 316 copies of questionnaire which represent $93.7 \%$ of the administered questionnaire were returned, checked and found usable.

Table 2. Business Information of the Respondents

\begin{tabular}{ccc}
\hline Category & Frequency & Percentage \\
\hline Age of the Business & 52 & 16 \\
$0-5$ & 107 & 34 \\
$6-10$ & 135 & 43 \\
$11-15$ & 22 & 7 \\
16 and above & 56 & 18 \\
Position & 75 & 24 \\
Owner & 185 & 58 \\
Manager &
\end{tabular}

Table 2 above shows vital information about the SSI operators. Majority of the SSIs (43\%) have been in existence for a period of 11-15 years (e.g. established between years 2005-2009), followed by 610 years old SSIs (34\%) (e.g. established between 2010-2014), then 0-5 years old SSIs (16\%) (e.g. established between 2015-2020), and only 7\% of SSI are more than 16 years old (e.g. established on or before 2004). Majority of the respondents (58\%) owns and manages their business enterprises, only $24 \%$ and $18 \%$ of the respondents 'manage but do not own the business' and 'owned but do not manage their businesses' respectively. 


\subsection{Normality test}

Basic descriptive statistics (mean, standard deviation, variance, skewness, and kurtosis) were computed to determine the normality of the research data prior to regression analysis.

Table 3. Descriptive Statistics

\begin{tabular}{ccccccccc}
\hline Variable & $\begin{array}{c}\text { Min. } \\
\text { Ma } \\
\text { x. }\end{array}$ & Mean & Sd. & Se(mean) & Variance & $\begin{array}{c}\text { Skewnes } \\
\text { s }\end{array}$ & kurtosis \\
\hline Operational performance & 44 & 90 & 72.55193 & 10.51803 & .5729537 & 110.629 & -.9398846 & 3.470102 \\
\hline Ambitious motivation & 13 & 25 & 22.95846 & 1.668527 & .0908905 & 2.783983 & -1.381751 & 9.037098 \\
\hline Compelling motivation & 11 & 30 & 26.06528 & 4.423478 & .2409622 & 19.56715 & -1.859128 & 5.833647 \\
\hline Facilitating motivation & 12 & 35 & 28.14243 & 4.271014 & .2326569 & 18.24156 & -.5896186 & 3.124921 \\
\hline \multicolumn{7}{c}{ Source: Field survey, 2020 }
\end{tabular}

Table 3 above shows that the dataset fulfills the normality assumption of regression since the skewness values range from -1 to +1 and the kurtosis values range from 1 to 9 . According to Kline (2016), if the skewness and kurtosis values are greater than 3 and 10 respectively, normality problem exists and vice versa. Consequently, the dataset of this study is normal since the Skewness and Kurtosis values are within the prescribed threshold. Furthermore, correlation and variance inflation factor (VIF) were processed and the results are presented in Tables 4 and 5 below.

Table 4. Correlation matrix

\begin{tabular}{ccccc}
\hline variables & $\begin{array}{c}\text { Operational } \\
\text { performance }\end{array}$ & $\begin{array}{c}\text { Ambitious } \\
\text { motivation }\end{array}$ & $\begin{array}{c}\text { Compelling } \\
\text { motivation }\end{array}$ & $\begin{array}{c}\text { Facilitating } \\
\text { motivation }\end{array}$ \\
\hline $\begin{array}{c}\text { Operational } \\
\text { performance }\end{array}$ & 1.0000 & & & \\
\hline Ambitious & $-0.1659^{*}$ & 1.0000 & & \\
motivation & 0.0022 & & & \\
\hline Compelling & $0.2878^{*}$ & $-0.1484^{*}$ & 1.0000 & 1.0000 \\
motivation & 0.0000 & 0.0063 & & \\
\hline Facilitating & $0.4890^{*}$ & $0.1245^{*}$ & 0.0753 & \\
motivation & 0.0000 & 0.0223 & 0.1680 & \\
\hline \multicolumn{5}{c}{ Source: Field survey, 2020 } \\
\end{tabular}

Table 4 shows a negative correlation between ambitious factor and operational performance $(r=$ $-0.1659)$ which is significant $(\mathrm{p}=0.0022<\alpha=0.05)$. However, compelling motivation and organizational performance are positively correlated $(\mathrm{r}=0.2878)$ significantly $(\mathrm{p}=0.0000<\alpha=0.05)$; similarly, facilitating factor and operational performance are significantly positively correlated $(r=0.4890$; $(\mathrm{p}=0.0000<\alpha=0.05)$. Importantly, none of the correlation between the independent variables (ambitious versus compelling motivation $=-0.1484$; ambitious versus facilitating motivation $=0.1245$; and facilitating versus compelling motivation $=0.0753$ ) is high enough to introduce collinearity problem.

Table 5. Variance Inflation Factor

\begin{tabular}{ccc}
\hline Variables & VIF & 1/VIF \\
\hline Ambitious motivation & 1.04 & 0.959470 \\
\hline Compelling motivation & 1.03 & 0.969042 \\
\hline Facilitating motivation & 1.03 & 0.975524 \\
\hline Mean VIF & 1.03 & \\
\hline Source: Field survey, 2020
\end{tabular}

To verify if multicollinearity problem that can have a damaging effect on multiple regression exist, a Variance Inflation Factory (VIF) analysis was processed. Table 5 shows the VIF of 1.04, 1.03 and 
1.03 for ambitious, compelling and facilitating motivations respective; all the VIF are less than 10.00 suggesting that multicollinearity is not a problem. Hair, Black, Babin and Anderson (2010) pointed out that multicollinearity is a problem when the VIF values are above 10 . This normally makes the coefficients not to be statistically significant by inflating the standard errors of the coefficients (Tabachnick \& Fidell, 2007).

\subsection{Test of hypotheses}

The results regarding test of research hypotheses are presented in Table 6 below:

Table 6: Regression results

\begin{tabular}{|c|c|c|c|c|c|c|c|c|}
\hline Number & 337 & Operational & Coef. & Robust & $\mathbf{t}$ & $p>|t|$ & [95\% con & Interval] \\
\hline$F(3,333)$ & 42.79 & $\begin{array}{l}\text { Ambitious } \\
\text { motivation }\end{array}$ & -1.228187 & .3152064 & -3.90 & 0.0000 & -1.848234 & -.6081403 \\
\hline Prob $>$ F & 0.0000 & $\begin{array}{l}\text { Compelling } \\
\text { motivation }\end{array}$ & .5266293 & .0969092 & 5.43 & 0.0000 & .3359979 & .7172608 \\
\hline R-squared & 0.3389 & $\begin{array}{l}\text { Facilitating } \\
\text { motivation }\end{array}$ & 1.22298 & .1304083 & 9.38 & 0.0000 & .9664517 & 1.479507 \\
\hline Root MSE & 8.5903 & _cons & 52.60484 & 7.715712 & 6.82 & 0.0000 & 37.42716 & 67.78253 \\
\hline
\end{tabular}

Table 6 reveals the regression results. First, the R-squared value of 0.3389 suggests that $33.89 \%$ of the variation in the dependent variable (operational performance) is explained by the independent variable (entrepreneurial motivation). The F-cal (42.79) is significant at p-value of 0.000, which confirms the robustness of the model in explaining the effect of entrepreneurial motivation on SSI operational performance.

Specifically, ambitious motivation is a significant predictor of operational performance $(t=-3.90$; $p=0.000<\alpha=0.05)$, though in a negative direction $(\beta 1=-1.228)$; that is, an increase in ambitious motivation by 1 unit will decrease operational performance by 1.228 units. Furthermore, compelling motivation has a positive and significant effect on the SSI operational performance $(\beta 2=0.526 ; t=5.43$; $\mathrm{p}=0.000<\alpha=0.05$ ) which indicates that an increase in compelling motivation by 1 unit will increase SSI operational performance by 0.526 units. Regarding the effect of facilitating factor on SSI operational performance, the outputs $(\beta 3=1.222, \mathrm{t}=9.38$ and $\mathrm{p}=0.000<\alpha=0.05)$ are positively significant, which connotes that operational performance will increase by 1.222 units anytime facilitating motivation increases by 1 unit.

Specification test was performed after the regression model for possible specification error in the model, to avoid biasness and inconsistency. The linktest presented shows the predictor (_hatsq) for rebuilding the model is insignificant (Pregibon, 1980). Given the insignificant value of the predictor, it therefore shows that the model is correctly specified.

\subsection{Findings and managerial implications}

The first finding is that entrepreneurial motivation is significantly impactful on the operational performance of SSI in Yanya, which is consistent with the earlier findings of related studies such as Tanveer et'al. (2019), Gundolf et'al. (2017) and Nasib et'al. (2019). Specifically, the facilitating motivation is the strongest positive predictor of SSI's performance $(\beta 3=1.222)$, followed by compelling motivation $(\beta 2=0.526)$. Policy-wise, Nigerian government has a major role to play in enhancing facilitating motivators such as public utilities, tax relief, entrepreneurial education, and increase access to credit because the gains from such entrepreneurial facilitating policies and actions outweigh their costs. The forgoing is fundamental considering the fact the major problems (for example, inadequate electricity 
and water supply; bad roads; low access to business credit; illegal multiple tax operations; cumbersome business registration, property acquisition, contract enforcement and security assurance procedures) bedeviling SSI in Nigeria revolves around facilitating factors (PwC, 2020; Kale, 2019). Managerial-wise, the facilitating motivators (e.g. funds, implements and other incentives) provided by the government should be regarded by the practicing entrepreneurs as levers for business expansions and not diverted to non-business pursuits. In addition, the entrepreneurs and managers have implied civic responsibility of ensuring proper usage of the public infrastructure for the attainment of their projected life-span. As these SSIs grow within their clusters and beyond, their managers should imbibe the culture of corporate social responsibility so as to facilitate rebirth and growth of new SSIs as well as future entrepreneurs.

Table 7. Specification Test

\begin{tabular}{|c|c|c|c|c|c|c|}
\hline Source & ss & Df & MS & $\begin{array}{c}\text { Number of } \\
\text { obs }\end{array}$ & 337 & \\
\hline Model & 12658.9351 & 2 & 6329.46753 & $\mathrm{~F}(2,334)$ & 86.24 & \\
\hline Residual & 24512.4062 & 334 & 73.3904377 & Prob $>$ F & 0.0000 & \\
\hline \multirow[t]{3}{*}{ Total } & 37171.3412 & 336 & 110.628992 & R-square d & 0.3406 & \\
\hline & & & & $\begin{array}{c}\text { Adj R- } \\
\text { squared }\end{array}$ & 0.3366 & \\
\hline & & & & Root MSE & 8.5668 & \\
\hline $\begin{array}{l}\text { Operational } \\
\text { performance }\end{array}$ & Coef. & Std. Err. & $\mathrm{t}$ & $P>|t|$ & \multicolumn{2}{|c|}{ 95\% Conf. Interval } \\
\hline _hat & -.1048273 & 1.216533 & -0.09 & 0.931 & -2.49786 & 2.288206 \\
\hline _hatsq & .0079142 & .0086973 & 0.91 & 0.363 & -.0091941 & .0250225 \\
\hline _cons & 38.20269 & 42.34859 & 0.90 & 0.368 & -45.10088 & 121.5063 \\
\hline
\end{tabular}

The caliber of entrepreneurs motivated into SSI by compelling factors keep exhaling in performance $(\beta 2=0.526)$, perhaps due to fear of returning to prior unemployment status in the event that the business fails. Such sustained dedication can translate to the creation of new jobs as the SSI expands. Thus, policy intervention (e.g. facilitating motivators and stimulants) can further boost the necessity entrepreneurs' productivity if injected at this juncture.

\section{Conclusions and Recommendations}

Recognizing that individual decisions to start, sustain and grow entrepreneurial firms are stimulated by motivational factors, an inquiry regarding the effect of entrepreneurial motivation on the operational performance of SSI in Yanya suburb of Abuja was deemed necessary. Based on the study's findings, the following conclusions were drawn: first, entrepreneurial motivation significantly influences performance of SSIs in Yanya; second, facilitating motivational factor is the strongest predictor of SSIs' performance in Yanya; third, compelling motivational factor is another strong predictor of SSIs' performance in Yanya; and fourth, ambitious motivational factor significantly predict SSIs' performance negatively in Yanya.

Therefore, the study recommends that all tiers of government in Nigeria should collaborate with the organized private sector to improve investment on the physical infrastructure - a component of the facilitating entrepreneurial motivation - (e.g. electricity generation, transmission and distribution; water supplies; and roads) especially in the environs of industrial estates and business hubs. Similarly, the soft aspects of facilitating entrepreneurial motivation (e.g. accessing credit, tax reliefs, zero-cost formalization of businesses, and training schemes) should feature in government entrepreneurship 
development and motivation policies on continuous bases so as to ameliorate the growing unemployment rate in Nigeria.

\subsection{Limitations and further studies}

The scope of this study is limited to small scale industries in Yanya, which restricted the generalization of the study's findings. Therefore, further studies are encouraged on same topic but with different and wider geographical scope in any part of Nigeria. Furthermore, the research design ignored the role of moderating variables (e.g. gender and age) in re-defining the research findings; thus, future studies may examine the moderating role of gender and age in testing the effect of entrepreneurial motivational factors on performance of small scale industries.

Author Contributions:

Conceptualization: The study was first conceived by the lead author, Mohammed Abubakar Mawoli and later discussed with the co-author, Ugbedeojo Nelson Peterfor for execution. Methodology: Both authors design the methodology and suggested STATA for data analysis. Validation: Instrument validation was carried out my M.A. Mawoli Formal analysis: Data analysis and brief interpretation of results was done by U.N. Peter. Investigation: Field work which involved questionnaire administration and collation was coordinated by U.N. Peter. Resources: Both authors contributed the financial and material resources required for the project. Data curation: This was handled by U.N. Peter. Writing: The original draft was prepared by M.A. Mawoli, while the review and editing was jointly done by the two authors. Visualization: M.A. Mawoli was responsible for visualization. Supervision: The lead author, being the most senior academic, supervises the entire exercise. Project administration: Both authors play key roles in the project administration.

Funding: This research received no external funding.

Conflicts of Interest: The authors declare no conflict of interest.

All authors have read and agreed to the published version of the manuscript.

\section{References}

Abdulsalam, D. \& Mawoli, M.A. (2012). Motivation and job performance of academic staff of state universities in Nigeria: the case of Ibrahim Badamasi Babangida University, Lapai, Niger State. International Journal of Business and Management, 7(14), 142-148. Web-site: http://dx.doi.org/10.5539/ijbm.v7n14p142

Alderfer, C.P. (1972). Existence, relatedness and growth: human needs in organizational setting. New York: Free Press.

Anton van de Rijdt, C. (2014). Intrinsic and Extrinsic motivational orientation for entrepreneurs: results and motivation, University of Amsterdam.

Baraba-Sanchez, \& Atienza-Sahuquillo, C. (2012). Entrepreneurial behaviour: impact of motivational factors on decision to create a new venture. Investigaciones Europeas de Direccion Economia de la Empresa, 18, 132-138.

Basheikh, A.M. \& Abdel-Maksoud, A. (2008). Operational performance measures used and contemporary management practices deployed in manufacturing firms: the case of Kingdom Saudi Arabia.

Black, J.S., Bright, D.S., Gardner, D.G. \& Hatmann, E. (2019). Organizationa Behavior, Texas: Rice University. Website:

Boada-grau, J., Sachez-Gercia, J.C., Viardot, E., Boada-Cuerva, M. \& Vigil-Colet, A. (2016). Adaptation of an entrepreneurial motivation scale into Spanish. Anales de Psicologia, 32(2), 571-577.

Bourles, R. \& Cozarenco, A. (2018). Entrepreneurial motivation and business performance: evidence from a French microfinance institution. Small Business Economics, Springer Verlag, 51(4), 943-963. Doi:10.1007/s11187-0179961-8.

Brody, N. \& Ehrlichman, H. (1998). Personality Psychology. Upper Saddle River, NJ: Prentice Hall.

Charles, V. \& Gherman, T. (2013). Factors influencing peruvian women to become entrepreneurs. World Applied Sciences Journal, 27(10), 1345-1354.

Collins, C., Locke, E. \& Hanges, P. (2000). The relationship of need for achievement to entrepreneurial behavior: a meta-analysis. Working paper, University of Maryland, College Park, MD.

Das, D.C. (2016). Influence of motivational factors on entrepreneurship: a study of Rangia development block under Rangia sub-division in Kamrup District, Assam. International Journal of Humanities and Social Science, $5(2), 38-44$. 
Dess G. G. \& Robinson R. B., Jr. (1984). Measuring organizational performance in the absence of objective measures: The case of the privately-held firm and conglomerate business unit. Strategic Management Journal, 5, 265-273.

Dobre, O. (2013). Employee motivation and organizational performance. Review of Applied Socio-Economic Research, $5(1), 53-60$.

Farzana, R. (2018). The impact of motivational factors towards entrepreneurial intention. Journal of Modern Accounting and Auditing, 14(12), 639-647. Doi:10.17265/1548-6583/2018.12.001.

Fereidouni, H.G., Masron, T.A., Nikbin, D. \& Amiri, R.E. (2010). Consequences of external motivation in Iran. Asian Academy of Management Journal, 15(2), 175-196.

Frese, M. \& Gielnik, M.M. (2014). The psychology of entrepreneurship. Annual Review of Organizational Psychology and Organizational Behavior, 1(1), 413-438.

Gangadhara-Rao, N. (1986). Entrepreneurship and Growth of Enterprises in Industrial Estate. New Delhi: Deep \& Deep Publications.

GEM (2019). 2020 global report. London: Global Entrepreneurship Research Association.

Guilford, J.P. \& Fruchter, B. (1973). Fundamental statistics in psychology and education. New York: McGraw Hill.

Gundolf, K., Gast, J. \& Geraudel, M. (2017). Startups' innovation behaviour: an investigation into the role of entreprenurial motivation. International Journal of Innovation Management, 21(7), 1-26. Doi: 10.1142/S136919617500542.

Hadli, N.H.B. (nd.). The determinant of firm operational performance.

Hair Jr, J. F., Black, J. W., Babin, B. J. \& Anderson, E. R. (2010). Multivariate Data Analysis (Seventh ed.). Edinburgh: Pearson Education Limited.

Heizer, J. R. (2008). Principles of operation management. PA: Pearson Prentice Hall.

Hill, T. (2000). Operations Management - Strategic Context and Managerial Analysis. London: Macmillan.

Hossain, M.U., Al Asheq, A. \& Arifuzzanman, S.M. (2019). Entrepreneurial intention of Bangledeshi students: impact of individual and contextual factors. Problems and Perspectives, 17(14), 493-503.

Johnson, B. (1990). Toward a multidimensional model of entrepreneurship: the case of achievement motivation and the entrepreneur. Entrepreneurship Theory and Practice, 14(3), 39-54.

Kale, Y. (2019). Micro, small and medium enterprises (MSME) national survey 2017 resport.

Kirkwood, J. (2009). Using multiple paradigm research methodologies to gain new insights into entrepreneurial motivations. Journal of Enterprising Culture, 15(3), 219-41.

Kishore, S. Raju, S.S. \& Dasaraju, H. (2012). Fostering entrepreneurship in MSMEs - a study of influence factors in Chittorr District of Andhra Pradesh. International Journal of Management Research and Review, 2(8),13691381.

Kline, R. B. (2016). Principles and practice of structural equation modelling (4th ed.). London: The Guilford Press.

Kreitner, R. (1989). Management (4th ed.). New York: Houghton Mifflin.

Kuranchie-Mensah, E.B. \& Amponsah-Tawiah, K. (2016). Employee motivation and work performance: a comparative study of mining companies in Ghana. Journal of Industrial Engineering and Management, Omnia Science, Barcelona, 9(2), 255-309.

Lalhunthara (2013). Entrepreneurship in micro-enterprises in Aizawl District, Mizoram, Department of Commerce, Mizoram University.

Langton, N., Robbins, S.P. \& Judge, T.A. (2016). Organizational behavior: concepts, Controversies, applications (7 $7^{\text {th }}$ Canadian edition), Toronto: Pearson Inc.

Lin, S. T. C. (2007). Sources of competitive advantage for emerging fast growth small-to-medium enterprises: The role of business orientation, marketing capabilities, customer values, and firm performance. Sydney: Royal Melbourne Institute of Technology.

McClelland, D. C. (1961). The achieving society. Princeton, NJ: Van Nostrand.

Mawoli, M.A. \& Babandako, A.Y. (2011). An evaluation of staff motivation, dissatisfaction and job performance in an academic setting. Australian Journal of Business and Management Research, 1(9), 1-13.

Murthy, BEVVN, Chandrasekhar, M. \& Rao, M.G. (1986). Entrepreneurial process, premises, decision, in Gupta, C. B. and Srinibasan, N.P. (Ed.) Entrepreneurial Development, New Delhi: Sultan Chand and Sons.

Naffziger, D.W., Hornsby, J.S., \& Kuratko, D.F. (1994). A proposed research model of entrepreneurial motivation. Entrepreneurship: Theory and Practice, 18(3), 29-42.

Narasimha-Murthy, B.E.V.V (1989). Entrepreneurship in Small Towns. New Delhi: Mittal Publication.

Nasib, S., Sulong, R.S. \& Amirul, S.M. (2019). An exploratory study of entrepreneurial motivation on informal entrepreneurs in Sabah. International Journal of Entrepreneurship Management Practices, 2(7), 1-12. Doi:10.35631/ijemp.27001. 
Nisula, A., Olander, H. \& Henttonen, K. (2017). Entrepreneurial motivation as drivers of expert creativity. International Journal of Innovation Management, 21(5):1-19. Doi: 10.1142/S1363919617400059.

NBS (2020). Unemployment rate in Nigeria: 2006-2020 data.

Ogunnaike, O.O., Aribisala, A., Ayeni, B. \& Osoko, A. (2019). Maslow theory of motivation and perfromance of selcted technology entrepreneurs in Nigeria. Inetranational Journal of Mechanical Engineering and Technology, 10(2):628-635.

Pregibon, D. (1980). Goodness of link tests for generalized linear models. Applied Statistics, 29(1), 15-23

PwC (2020), PwC's MSME survey 2020: building to last (Nigerian report).

Rao, V., Venkatachalm, A. \& Joshi, H.G. (2013). A study of entrepreneurial characteristics and success of women entrepreneurs operating fashion and apparel business. Asian Journal of Management Sciences and Education, 2(2), 136-147.

Reynolds, P.D., Camp, S.M., Bygrave, W.D., Autio, E. \& Hay, M., (2001). Global Entrepreneurship Monitor: Executive Report. London: Babson College, London Business School and Kauffman Foundation.

Robichaud, Y., Cachon, J. C. \& Haq, R. (2010). Motives, success factors, and barriers among Canadian female entrepreneurs: The case of Greater Sudbury. Entrepreneurial Practice Review, 1, 36-65.

Sayyar, L.Z., Latifi, S., Sarempoor, Q. and Pirmoradi, A. (2012). Factors facilitating entrepreneurship and self-employment in agriculture sector. Life Science Journal, 9(4), 2423-2430.

Shane, S. (2009). The illusions of entrepreneurship. New Haven: Yale University Press.

Slack, N. C. (2004). Operations Management. London: Prentice Hall, Harlow.

Social Welfare Office (2020). Membership registration: small scale induries in Yanya. Unpublished.

Stam, E., Bosma, N., Witteloostuijn, A., Jong, J., Bogaert, S., Edwards, N. \& Jaspers, F. (2012), Ambitious entrepreneurship: a review of the academic literature and new directions for public policy. Advisory Council for Science Technolgy Policy.

Tabachnick, B.G. \& Fidell, L.S. (2007). Using Multivariate Statistics (5th ed.). New York: Pearson.

Tanveer, M.A., Zafar, S., shafique, R., Jhangir, M. \& Rizvi, S. (2013). Motivational factors and students entrepreneurial intention in Pakistan. Journal of Basic Applied Sciences, 3(4), 263-269.

Tettey, A. (2014). Entrepreneurial motivation and firm performance of small and medium enterprises in New Jauben Minicipality, MBA Dissertaion, Department of Management Studies, University of Cape Coast.

Ullah, H., Farooq, M.A. \& Ahmad, Z.M. (2012). A study of psychological and non-psychological factors of owner influencing entrepreneurial orientation: evidence from Khyber Pakhtunkhwa-Pakistan. Management Science and Engineering, 6(1), 44-55. Doi: 10.3968/j.mse.1913935X20120601.2700.

Venkataraman, N. (1997). Measurement of business performance in strategy research: A comparison of approaches. The Academy of Management Review, 11(4), 801-814.

Vijaya, V. \& Kamalanabhan, T.J. (1998). A scale to assess entrepreneurial motivation. Journal of Entrepreneurship, 7(2), 183:198. Doi: 10.1177/097135579800700204.

Yitshaki, R. \& Kropp, F. (2018). Revisiting entrepreneurial motivation and opportunity recognition, in M. Brannback and A.L. Carsrud (Eds.), A research agenda for entrepreneurial cognition and intention, 122-144, Edward Elgar Publishing. Doi: 10.5465/AMBPP.2018.17205abstract.

(C) 2020 by the authors. This article is an open-access article distributed under the terms and conditions of the Creative Commons Attribution (CC BY) license (http://creativecommons.org/licenses/by/4.0/). 